\title{
CHINESE LEGAL TERMINOLOGY IN EUROPEAN AND ASIAN CONTEXTS ANALYSED ON THE EXAMPLE OF FREEDOM OF CONTRACT LIMITS RELATED TO STATE, LAW AND PUBLICITY
}

\begin{abstract}
The aim of this research was to analyse Chinese legal terminology related to limits of freedom of contract in juxtaposition with other European and Asian legal systems. The study was limited to state, law and publicity. The purpose of the comparison was to add a broader perspective to the research on Chinese legal terminology. The research material included civil codes and contract laws of selected European and Asian countries. Among the European codes the great ones were obviously included - French, Austrian and German, as well as those of less importance, but still relevant in Europe, such as Italian, Spanish codes or Swiss Law of Obligation, and also codes of Slavic and simultaneously post-socialist countries, like Poland, Czech Republic and Russia. In the case of Asia, the codes of China, Japan, South Korea and Vietnam were analysed. The question asked was whether the terminology used in Chinese law is unique or repeated and if so, how common it is in comparison with other legal systems. The research methods included the parametric approach to legal terminology comparison and techniques of legal construction (interpretation).
\end{abstract}

Keywords: freedom of contract, legal language, legal terminology, Chinese legal language, Chinese legal terminology.

\section{Abbreviations}

CC - civil code

CCD - Collins Chinese Dictionary (2011. Glasgow: HarperCollins Publishers)

CL - Contract Law of 1999 (Chinese)

GMD - Guomindang (Chinese National Party)

GPCL - General Principles of Civil Law of 1986 (Chinese)

POCD - Pocket Oxford Chinese Dictionary English-Chinese Chinese-English (2009. Oxford: Oxford University Press)

\section{Introduction}

Modern Asian laws are to the great extent inspired by Western codifications, with German, French and Swiss codes as the most influential. The 


\section{Paulina Kozanecka}

question posed in this paper was whether the linguistic expression of freedom of contract rule as well as its limits in Chinese legal texts is unique or common against those included in Western and other East-Asian laws, and to find particular similarities and differences. Therefore the main aim of the paper was to compare the terminology used in context of freedom of contract in selected European and Asian legal systems. Due to the vastness of the topic, only the terminology of limits related to state, law and publicity was considered. Among the European codes, the great ones were obviously included - French, Austrian and German ones, as well as those of less importance, but still relevant in Europe, such as the Italian, Spanish CCs or the Swiss Law of Obligation, and also codes of Slavic and simultaneously post-socialist countries, such as Poland, Czech Republic and Russia. In regard to Asia, the codes of Japan, South Korea and Vietnam were analysed. The purpose of such selection was to analyse the old model codes (such as German, French or Austrian), those that had connections to political systems similar to the Chinese (such as Polish, Russian or Vietnamese), those that are rooted in the European tradition, but were issued in the modern period (for example Spanish or Italian), codes that come from cultures similar to the Chinese (Japanese or Korean), as well as relatively recently issued codes (e.g. Czech and Vietnamese). They were analysed in chronological order, from the oldest to the newest, but were divided into European and Asian categories. All of them were investigated in tandem with the Chinese regulations on freedom of contract and its limits related to state, law and publicity. The provisions were taken into account very briefly, only to give an idea how the Chinese regulations are placed in a global context, and to retrace possible connections.

Currently the development of legal systems leads to the restricting of freedom of contract, by introducing protective rights, for example consumer rights. However, in this paper only general provisions included in civil codes or contract laws were analysed.

\section{Research material and methodology}

The analysed material included the two main Chinese laws on freedom of contract, that are: The General Principles of Civil Law (Zhonghua Renmin Gongheguo Hetongfa 中华人民共和国合同法, 1986, hereinafter called 'the Chinese GPCL') and Contract Law (Zhonghua Renmin Gongheguo Hetongfa 中华人民共和国合同法, 1999, hereinafter called 'the Chinese CL'). Moreover, the author examined in chronological order the civil codes and 
laws of obligations from nine selected European countries, namely France, Austria, Switzerland, Spain, Germany, Italy, Poland, Russia and Czech Republic, as well as three Asian states: Japan, South Korea and Vietnam.

In the research the method of analysis of comparable texts (formerly called parallel texts) was applied. The method requires a comparison of texts prepared originally in the languages under study, considering the same subject and the same aim. As a result it is possible to find the equivalents of terms used in the texts, as well as determine non-equivalent terms (Kubacki, 2013, p. 146). Equivalents identified through such a comparison are more reliable, since they are found in natural context and usage (Matulewska, 2010, p. 59). In this case provisions regarding freedom of contract in the respective laws were analysed in comparison with Chinese regulation.

In order to determine these provisions related to freedom of contract, the techniques of legal construction (interpretation) were also applied. It is necessary to recognise the exact meaning of a clause and the terms within it in legal context, since legal interpretation leads to a different understanding than its literal interpretation (Wan, 2012, p. 16). Finally the terminology was studied using the parametric approach to legal terminology comparison (cf. Matulewska, 2013). This approach implies establishing the relevant dimensions in the context of legal translation which helps in finding more accurate meanings and contexts of particular terms.

\section{Freedom of contract Regulation in Contemporary Chinese Law}

In Chinese law, freedom of contract is placed both in the Chinese GPCL, which play the role of the general part of the civil code, and in the Chinese CL. Since the provisions in the Chinese GPCL are general provisions for the whole of Chinese civil law, they refer to minshi huodong 民事活动 'civil activity', which includes both civil legal acts and other acts related to civil matters. More about freedom of contract and its limits can be found in further articles from the section regarding minshi falü xinwei 民事法律行为 'civil legal acts', which is a narrower term in comparison with minshi huodong 民事活动 'civil activity'. It is also worth mentioning that Chinese GPCL in this section uses two terms: minshi xinwei 民事行为 'civil act' and minshi falü xinwei 民事法律行为 'civil legal act'. However these two terms should be treated as equivalents (Wei, 2013, p. 140). More legal rules referring to freedom of contract is placed in specific laws, such as the Chi- 
nese CL. Freedom of contract, however, is a subject to numerous limits and in the Chinese legal system many of them are related to law, state and publicity. Both in GPCL and CL the following restrictions can be found within this scope:

1. law:

a. falü 法律 'law' / yifa 依法 'accordance with law',

b. xingzheng fagui 行政法规 'administrative regulations',

c. feifa mudi 非法目的 'illegitimate purpose';

2. state:

a. guojia zengce 国家政策 'state policies',

b. guojia liyi 国家利益 'state interest',

c. guojia zhiling xing renwu 国家指令性任务 'mandatory state tasks',

d. guijia dinghuo renwu 国家订货任务 'state purchasing tasks';

e. guojia jingji jihua 国家经济计划 'state economic plans';

3. publicity:

a. shihei jingji zhixu 社会经济秩序 'social economic order',

b. gonggong liyi 公共利益 'public interest',

c. shehui gonggong liyi 社会公共利益 'social public interest',

d. jiti liyi 集体利益 'collective interest'.

\subsection{Law}

The postulate of lawfulness is expressed in Art. 4 of the Chinese GPCL and is further repeated in several articles of the Chinese GPCL and the Chinese CL. Articles 54, 55 and 58 of the Chinese GPCL are interesting due to their references to law and state-related provisions. Art. 54 of the Chinese GPCL also underlines the required hefa 合法 'lawfulness' of the civil legal act. Although it should not be surprising that the act must be lawful, the constant repetition of that requirement appears to be unnatural. For example, just the following Art. 55 of the Chinese GPCL indicates that violating 'laws' is forbidden. It seems that this is one of ways China tries to establish the rule of law. Art. 58 of the Chinese GPCL indicates when a specified factor causes invalidity of a contract, it is therefore considered as certain limit of contractual freedom. And again (!) section 5 enumerates violating falü 法律 'law', this time as prerequisite of invalidity. Moreover, an additional restriction of being yifa 依法 'in accordance with law' is repeated in many articles, for instance in Art. 7, 38, 44, 52 and 127 of the Chinese CL.

Part of the Chinese CL provisions is just a repetition of the Chinese GPCL articles. For example, the clause of being in accordance with laws and administrative regulations constantly reappears in vari- 
ous combinations. Incidentally, falü, xinzheng faguide qiangzhixing guiding 法律、行政法规的强制性规定 'compulsory provisions of laws and administrative regulations' mentioned in section 5 of Art. 52 of the Chinese CL were clarified by Chinese Supreme People's Court in Art. 14 of the Second Court Interpretation of the Chinese CL as xiaolixing qiangzhixing guiding 效力性强制性规定 'mandatory provisions on validity' (cf. Sun et al., 2013). According to Han (2012, p. 250), this clarification indicates that only violation of "provisions on effectiveness" results in the invalidity of a contract, while violating an administrative provision will not make a contract void. Nevertheless, Zhou (2003, p. 98) observes that the Chinese CL shortened the list of circumstances that make contracts void and made them more explicit. This was due to the strengthening stability of contract relationships and simultaneously preserving state, social and also public interests. Furthermore, Art. 52 of the Chinese CL focuses also on feifa mudi 非法目的 'illegitimate purpose'. If the intention of the parties was, for example, to evade taxes or to steal something under disguise of a lawful contract, it will result in the invalidity of the whole contract, even if all the requirements were fulfilled for the contract to be in accordance with the law (Zhang, 2006, p. 179).

\subsection{State}

Some limits to freedom of contract related to state can be observed in Art. 6 and 7 of the Chinese GPCL. The first one indicates that civil activities should proceed in accordance with the law, and if there are no specific laws, it still should not violate guojia zengce 国家政策 'state policies'. This aspect appeared once in the Chinese Economic Contract Law (1981, now repealed; abbreviated as ECL), and was generally removed from it by the 1993 Amendment. It should be noted though that the Chinese GPCL was promulgated in 1986, which was just five years after the ECL. Thus the impact of this provision depends on the fact whether or not there are the specific laws. Kornet (2010, p. 11) observes that under the ECL, in accordance with the law, is itself in accordance with state policy, whilst the Chinese CL does not continue this concept. And, according to Zhang (2006, p. 61), this is so because Chinese legislator did not want to create such an uncertainty of law (since the state policies may change), with the aim of not discouraging foreign investors. However, another term used instead is guojia liyi 国家利益 'state interest'. This one may be as well found in numerous other Chinese legal provisions, and is quite flexible, allowing judges to justify severe interference of the state in private law. 


\section{Paulina Kozanecka}

On the other hand Art. 7 of the Chinese GPCL mentions guojia jingji jihua 国家经济计划 'state economic plans', which were derogated from the Economic Contract Law in 1993 and apparently it seems that here they have remained. However it should be noted that this article refers to 'state economic plans' and not just 'state plans'. Furthermore, section 6 in Art. 58 of the Chinese GPCL mentions guojia zhiling xing jihua 国家指令性计划 'mandatory state plans', which were deleted from the Economic Contract Law in 1993. However, as it will be explained below, currently the state plans do not play such a predominant role in the Chinese economy.

Art. 38 of the Chinese CL recalls once again the mandatory tasks of the state, which recall those state mandatory plans which earlier were the core of the Economic Contract Law and appeared also in the Chinese GPCL. It is of interest that whilst the Chinese GPCL mentions guojia zhiling xing jihua 国家指令性计划, which is translated as 'mandatory state plans', the Chinese CL speaks of guojia zhiling xing renwu 国家指令性任务, which in many cases is translated in the same way (Kornet, 2010, p. 10), but it should be noted that they differ by the two last characters. Jihua 计划 and renwu 任务 are not equivalents, since while jihua 计划 means 'plan' (POCD: 'plan, programme'; CCD: 'plan') and is used in phrase jihua jingji 计划经济 'planned economy' (POCD), renwu 任务 meaning is 'task', 'mission', 'assignment' (POCD: 'task, mission, assignment', CCD: 'task'). In fact, the state can announce a mandatory plan, which, to be accomplished, needs several specified mandatory tasks to be carried out (Wu et. al., 2012). Therefore, although the provisions from the Chinese GPCL and the Chinese CL differ, (indeed they mention the same processes), they do so respectively in their general and particular essences, since the Chinese CL does not refer to state plans directly (Ling, 2002, p. 47). Zhang (2006, p. 120) defines the 'state mandatory task' as 'the task assigned by the state through administrative means and must be taken and accomplished by the entities affected'. Another meaning of the realisation of the state's plans include guijia dinghuo renwu 国家订货任务 'state purchasing tasks'. According to Zhang (2006, p. 120) such a task is "the order placed by one business entity designated by the state to make a purchase from another business entity". But does this mean that nothing has changed since the ECL? Kornet (2010, p. 10) holds the view that a change is apparent, since although some remnants of the state plans remain in CL, in reality the state seldom issues mandatory plans and only in certain economic areas - although it is significant that this severe limit of contractual freedom is still possible (Zhang, 2006, p. 120). Hsu (2007, p. 122) observes that although in these cases state plans remained in the legal provisions, in practice there are not 
Chinese Legal Terminology in European and Asian Contexts Analysed...

many mandatory state plans, so the situations these articles refer to are rather rare. However, noticeably these articles contain a whole series of potential restrictions.

\subsection{Publicity}

Art. 7 of the Chinese GPCL mentions shihei jingji zhixu 社会经济秩序 'social economic order' as a factor that can limit civil activity (and, therefore, contracts too). (Song and Guo, 2013, p. 17). Shihei jingji zhixu 社会经济秩序 in official translations is translated differently - as 'social economic order' or 'social and economic order'. Nevertheless, it is treated as one term, consisting of two aspects (social and ecenomic).

In the same article the limit of shehui gonggong liyi 社会公共利益 'social public interest' is included. Art. 55 of the Chinese GPCL also mentions that shehui gonggong liyi 社会公共利益 'social public interest' cannot be infringed and in Article 58 of the Chinese GPCL it is included as well. It is though a term different from gonggong liyi 公共利益 'public interest' and jiti liyi 集体利益 'collective interest' - the former is broader in its meaning, and the latter focuses only on the interest of collectives.

Moreover, it is noticeable that in these provisions the role of state and public interest is also limiting freedom of contract. According to $\mathrm{Fu}$ (2013, p. 276), this is a result both of recent Chinese socialist history, which focused on the collective interest rather than on private issues, and the Confucian tradition, that stressed the importance of a group and public interest, and not of an unit's and private interest. Art. 127 of the Chinese CL is also a kind of a tool of state. In a case where the interests of state were to be threatened, this provision allows the state bureaucracy to supervise the contract being concluded. Zhou (2003, p. 95) indicates that the used term shehui gonggong liyi 社会公共利益 'social public interest' 'is a rather abstract concept, which is generally interpreted as social and public order, good custom, moral standards etc." and may be perceived as an additional supervision of society next to the laws. The problem of the uniqueness of this Chinese term against other legal systems was also studied by Liu (2017). Similarly, Zhang (2006, p. 63) aptly states that since there are no specific provisions on the scope of this supervision or any procedural rules for it, the boundary between supervision and intervention might be unclear and may lead to lawful interference in contracts. In practice, for example, the civil service issues model contracts, which can be optionally used by parties if they want to be sure that they do not violate any mandatory rule. But though the use of models is facultative, in fact it is "strongly encouraged in practice". 


\section{Freedom of contract in European Legal Tradition}

Since European law has grown on the basis of Roman law and also European legal systems had a lot of influence on each other due to numerous historical relations between countries, the differences should not be significant. Notwithstanding, there are some dissimilarities that can be noticed. Among European legal systems, those of France, Switzerland, Spain, German, Italy, Poland, Russia and Czech Republic were selected and analysed in chronological order, from the oldest to the newest.

Due to the narrow remit of this paper, only the general provisions on freedom of contract from the respective civil codes will be presented, excluding the special provisions from consumer law and other regulations.

\subsection{France}

The French Civil Code (Code civil) was the first modern civil code that was based on the achievements of the so-called school of natural law, and this is the reason why its influences are discernible in many other modern civil codes and other civil-law-related acts. It was introduced in 1804, during Napoleon's reign, and still - though amended - is in force today (Sójka-Zielińska, 2007, p. 67), but some major changes in field of law of obligations occurred due to the 2016 amendment (Soulier, 2016). Its influence can be found not only in Europe, where it was an inspiration for civil codes in, e.g., Romania, Italy, Portugal or Spain, but also for countries in North and South America, Asia and Africa (Sójka-Zielińska, 2009, pp. 220-221).

Article 1134 of the French CC indicates that agreements, to be considered binding, should be légalement 'lawful'. It is similar prerequisite to those that can be found in Art. 54 of the Chinese GPCL and Art. 4 of the Chinese CL.

On the other hand, the French $\mathrm{CC}$ contains such restrictions as l'ordre public 'public order'. This one was placed in the first Chinese civil code, that was 1930-Civil Code, issued by National Party (Guomindang Civil Code, Chinese GMD CC) in Art. 72, gonggong zhixu 公共秩序 'public order', and is not included in the contemporary Chinese law.

\subsection{Austria}

The Allgemeines bürgerliches Gesetzbuch comes from 1811 and as the second great modern European civil code, was also based on the thought of the school of natural law, assuming as its bases the equality of legal subjects, freedom of ownership and freedom of contract. It still remains in 
force, but was several times revised, due to great political and social changes in Austria (Zhang, 2006, p. 179).

The Austrian CC does not mention freedom of contract by itself, but in some aspects this issue is regulated by $\S 879$ (Sójka-Zielińska, 2009, pp. 218-219). The provision does not formulate the principle of freedom of contract, and rather presents its legal limits (Foster, 2013, p. 204). The two first restrictions are: the violation of ein gesetzliches Verbot'a statutory prohibition', which seems similar to Chinese falü, xinzheng faguide qiangzhixing guiding 法律、行政法规的强制性规定 'compulsory provisions of laws and administrative regulations' from Art. 52 section 5 of the Chinese CL - though it is not literally the same restriction (the Chinese term is defined by Chinese Supreme People's Court as "compulsory provisions on validity").

\subsection{Switzerland}

Although Switzerland has the civil code compiling civil matters in general, it does not cover the issue of contracts by itself. While mentioning contract, the Swiss Law of Obligations (Obligationenrecht) introduced in 1883 - which was meant to be the fifth book of the Swiss civil code (Lando et. al., 2003, p. 213) - should be recognised. The Swiss Law of Obligations has its version both in German and French (as Droit des obligations), so in this case both languages were analysed.

Freedom of contract is derived from Art. 11 and 19 Swiss Law of Obligations (Sójka-Zielińska, 2009, p. 227). Again boundaries drawn by des Gesetzes / la loi 'laws' are an important restriction of freedom of contract, such as Chinese falü 法律 'law'. However, it should be noted, that Swiss law, unlike Chinese, speaks only of laws and not of administrative regulations. Moreover, the Swiss Law of Obligation mentions public policy, or die öffentliche Ordnung / l'ordre public 'public order' and das Recht der Persönlichkeit in sich schliesst / droits attachés à la personnalité 'rights of personal privacy'. And again, these limits were included in Chinese GMD CC (gonggong zhixu 公共秩序 'public order'), but not in any later Chinese contract law.

Widerrechtlichen / illicite 'unlawful' terms are not considered by the Chinese law similarly, rather as feifa mudi 非法目的 'unlawful purpose' from Art. 52 section 3 of the Chinese CL and generally violation of falü, xinzheng faguide qiangzhixing guiding 法律、行政法规的强制性规定 'laws and administrative regulations' from Art. 52 section 5 of the Chinese CL. Unlike the Chinese, the Swiss law, as the previously analysed systems, does not mention administrative regulations along with laws. 


\section{Paulina Kozanecka}

\subsection{Spain}

The Spanish Civil Code, that is Código civil, was issued in 1889. It reflects a strong influence of the French CC, especially in parts regarding obligations, where many directly translated French provisions can be found (Morin, 2014, p. 215).

The Spanish CC formulates freedom of contract verbally, by means of Article 1255 of the Spanish CC. It is limited by both laws and public order, and also morality (Zweigert and Kötz, 1998, p. 107).

Art. 1255 of the Spanish CC mentions two main state-and-law-related restrictions to freedom of contract, these are: las leyes 'laws' and orden público 'public order'. Once again there is the limit of law - just as in China ( falü 法律 'law'), but 'administrative regulations' again are missing.

\subsection{Germany}

The German Civil Code, Bürgerliches Gesetzbuch, also belongs to the group of great codifications of $19^{\text {th }}$ century. Its foundation was thought to be of the Pandectist School, and it is perceived to be addressed not to the citizens, but rather to lawyers and legal scholars (Wojciechowska, 2013, p. 24). In many cases it presents an alternative approach to civil law than the French CC, being - similar to the French CC - an inspiration for various European and non-European later codes (Zweigert and Kötz, 1998 , p. 144). Examples of its influence will be discussed further in this paper, e.g. in the Japanese CC (Sójka-Zielińska, 2009, p. 226) - as well as Chinese law.

Freedom of contract is not expressed in German law either, for it is considered an obvious principle not required to be written down. It is derived from and also limited by $\S \S 134,137,242$ and 307 of the German CC. $\S 134$ of the German CC states that contract cannot stand against ein gesetzliches Verbot 'a statutory prohibition', which was prescribed also in the 1930 Chinese GMD CC by quite a literary translation of the German term: jinzhizji guiding 禁止之規定 'prohibitive provisions'. A similar restriction was placed in the Austrian CC. Analogically, as it was described in that subsection, in contemporary Chinese law some equivalent of 'statutory prohibition' may be the Chinese syntagm falü, xinzheng faguide qiangzhixing guiding 法律、行政法规的强制性规定 'compulsory provisions of laws and administrative regulations' from Art. 52 section 5 of the Chinese CL, nevertheless these two terms do not have entirely identical meanings.

Moreover, $\S 307$ of the German CC one more time recalls the condition of compliance with the statutory provisions, by referring to wesentlichen 
Grundgedanken der gesetzlichen Regelung 'essential principles of the statutory provision'. Similarly to $\S 134$ of the German CC, a clear reference to this provision can be seen in Art. 52 section 5 of the CL, where falü, xinzheng faguide qiangzhixing guiding 法律、行政法规的强制性规定 'compulsory provisions of laws and administrative regulations' are required.

But since the German CC does not define freedom of contract directly, currently the principle is derived from Art. 2 section 1 of the German Constitution (promulgated in 1949, as amended), and thus is thought to be the constitutional right laying at the basis of the whole German law (Dajczak, 2012, p. 149).

In that general provision three main restrictions are shown: die Rechte anderer 'the rights of others' - which is analogous to Chinese di san rende quanyi 第三人的权益 'third party interest' placed in Art. 52 section 2 of the CL; die verfassungsmäßige Ordnung 'the constitutional order' - which rarely can be found in Chinese law, but may be identified just with falü, xingzheng guiding 法律、行政法规 'laws and administrative regulations'.

\subsection{Italy}

In Codice civile, the Italian Civil Code, a French influence is also observable. Although the first Italian civil code comes from 1865, the current was issued in 1942. It is noteworthy that Italian provisions especially on the law of obligations are very similar to the French (Gebhardt and Schulz, 2003 , p. 7), which is clearly visible in the cited articles below.

Freedom of contract is exactly formulated in Art. 1322 of the Italian CC, whereas Art. 1325 of the Italian CC presents conditions of contract validity. Art. 1322 of the Italian CC mentions limits imposed by legge 'law', which is a restriction found also in many provisions of Chinese law as falü 法律 'law'. Moreover, according to Art. 1354 of the Italian CC a contract would be regarded void if it violated norme imperative 'imperative rules' and ordine pubblico 'public order'. These conditions are not included in present Chinese laws, though imperative norms were mentioned in the 1930 Chinese GMD CC in Art. 71 as qiangzhizhi guiding 強制之規定 'mandatory provisions' and gonggong zhixu 公共秩序 'public order' in Art. 72 of the Chinese GMD CC. In current legislation in Art. 52 section 5 of the Chinese CL faguide qiangzhixing guiding 法律、行政法规的强制性规定 'mandatory provisions of laws and administrative regulations' can be found, but as it was noted in the previous sections, from the linguistic point of view it is not an identical term and its scope of meaning is somehow different. 


\section{Paulina Kozanecka}

\subsection{Poland}

In Poland freedom of contract is clearly formulated in Art. $353^{1}$ of the Polish Civil Code (Kodeks Cywilny) of 1964. This rule though has not been in the Polish civil code since its very beginning. It was not there until $1990-$ with the end of communism the Polish civil code was extensively amended, including the introduction of the direct principle of freedom of contract (Zweigert \& Kötz, 1998, pp. 104-106).

Since the Polish regulation is relatively recent, it contains the rule of freedom of contract formulated directly in a separate article, what - as it can be seen in aforementioned codes - has not been a common practice in other analysed laws.

Art. $353^{1}$ of the Polish CC includes also a requirement of being in accordance with ustawa 'statute'. It is far narrower than the Chinese falü, xingzheng faguide qiangzhixing guiding 法律、行政法规的强制性规定 'mandatory provisions of laws and administrative regulations', since the Polish $\mathrm{CC}$ omits not only the administrative regulations, but also reduces the range of relevant laws only to the highest ones in the Polish legal system and only such provisions of these laws that are obligatory (Dajczak, 2012, p. 141). In this case the limits imposed by Chinese law is much wider.

\subsection{Russia}

Гражданский кодекс (Grazhdanskiy kodeks) is a post-Soviet codification, issued in 1994 (but the part concerning obligations was added in 1996). It clearly differs from the French CC and the German CC, and one can hardly notice their influence in it. However, some aspects of freedom of contract seem to be common, also for the Russian CC. Moreover, it should be noted that the current regulation has been introduced in Russia only after the great political transformation. (Radwański and Olejniczak, 2011, p. 286).

In the Russian CC freedom of contract is expressed directly, verbally in Article 421. Besides, there are also some provisions that limit the freedom and create a way for obligatory contracts. In Article 422 section 1 of the Russian CC freedom of contract is guaranteed, but the same provision stipulates that there are certain legally allowed circumstances when subjects would be forced to conclude a contract - however these situations are confined to these prescribed by the Code (Kodeksom Кодексом) - that is to say the Russian CC; by zakonom законом 'statutes'; or by dobrovolno priniatym добровольно принятым обязательствома 'a voluntarily assumed obligation'. This regulation can be in some way similar to the above mentioned 
Chinese guojia zhiling xing renwu 国家指令性任务 'mandatory state tasks', but it is not exactly the same.

The main restriction is indicated in Art. 422 of the Russian CC, that the contract cannot be contrary to rules provided zakonom $i$ inymi pravovymi aktami (imperativnym normam) законом и иными правовыми актами (императивным нормам) 'by statutes and by other legal acts (the imperative norms)'. On one hand it reflects the Chinese GMD CC provision by usage of the term qiangzhizhi guiding 強制之規定 'imperative norms', but also seems similar to current Chinese falü, xingzheng faguide qiangzhixing guiding 法律、行政法规的强制性规定 'mandatory provisions of laws and administrative regulations'.

Nevertheless, in the Russian CC apparently highly detailed provisions can be found, contrasting with aforementioned brief articles from the French CC or indirect regulation from the German CC. The Russian legislator tried to regulate freedom of contract in every aspect, seemingly akin to China, meanwhile the French or German version was clearly open for unpredicted cases which is indicated by the usage of more general terms.

\subsection{Czech Republic}

In the Czech Republic new Občanský zákonik - that means, the civil code - has been in force since 2014. In $\S 1$ (2) of the Czech CC some limits such as laws and morals can be seen, while $\S 1725$ of the Czech CC provides freedom of contract directly. In $\S 1725$ of the Czech CC freedom of contract principle is introduced. Moreover, the provision restricts it stipulating that parties are free to conclude any contract within právního řádu 'the legal order'. Therefore that limit is in line with the Chinese indication that the parties have a right to enter the contract yifa 依法 'in accordance with law'.

Moreover, $\S 1$ of the Czech CC gives general restrictions to contracting, that are veřejný pořádek 'public order' and právo týkajicı se postavení osob 'law regarding the status of persons', which is determined as including the right to privacy. Whereas the first restriction is one found in the Chinese GMD CC (gonggong zhixu 公共秩序 'public order'), the third one is more specific. It can be compared with di san rende quanyi 第三人的权益 'a third party interest', included in Art. 52 section 2 of the Chinese CL.

$N B$ in $\S 1725$ of the Czech CC, which is included in the chapter related to contracts, only law-connected limits are mentioned, while the moral norms clause is placed among the general provisions of civil law. Also $\S 1746$ additionally indicates that parties can conclude a contract type which is not covered by the code. 


\section{Freedom of Contract in Modern Asian Legal Systems}

Asian countries, though they are mostly both historically and geographically unrelated to Europe, have created modern legal systems that were to a certain extent modelled on European laws, and that is why some similar solutions can be observed. Taking examples from Asia, the legal systems of Japan, South Korea and Vietnam were analysed and ordered chronologically.

As stated in the introduction, at the turn of the $19^{\text {th }}$ and $20^{\text {th }}$ centuries Asian countries went against their own traditional laws and borrowed legal patterns from European countries, especially the $19^{\text {th }}$ century great codifications, among which the German CC happened to be the most influential (Dajczak, 2012, p. 113). It is worth analysing how the potential reception to freedom of contract looked in other Asian countries, to compare whether it was similar with the Chinese case or not.

\subsection{Japan}

The Japanese Civil Code (Minpō 民法) came into existence in 1898 under great influence of the German CC and the French CC (Kitagawa, 2008, p. 256), as well as other countries, such as the United States (Kitagawa, 2008, p. 244). The traditional Japanese law was not taken into account. The Japanese codification was almost a copy of the German CC, but, in contrast, Japanese society was far different from that in Germany (Kitagawa, 2008 , p. 257), due to the fact that it was deeply rooted in the Confucian tradition (Zweigert and Kötz, 1998, p. 298).

Nevertheless, since the Japanese CC was modelled on the German CC patterns, it also did not include the direct freedom of contract principle. What is interesting, the first version of the Japanese CC (from 1890) included a freedom of contract clause, but it was omitted in 1898 Japanese CC, since freedom of contract was deemed to be fundamental and thus a natural principle, which did not need to be written down (Zweigert and Kötz, 1998, p. 300). Therefore, as in German law, freedom of contract is derived from the Japanese Constitution (promulgated on November 3, 1946). The constitutional right of "enjoying any of the fundamental human rights" is not restricted therein. However, some restrictions may be found in the Japanese CC. In Art. 1 of the Japanese CC, which refers to civil rights in general, the restriction of being in accordance with kōkyo no fukushi 公共の福祉 'public welfare' is mentioned.

Furthermore, in Art. 90 of the Japanese CC, in the context of contracts only, compliance with $k \bar{o}$ no chitsujo 公の秩序 'public order' is required. 
This whole article reminds Art. 72 of the Chinese GMD CC, where additionally quite similar terms are used: gonggong zhixu 公共秩序 'public order'. Note that Japanese use Chinese characters as well - it is interesting that Japan first borrowed Chinese characters and adapted them to the legal language, and then China borrowed the basics of legal language from Japan, which already conveniently consisted of Chinese characters (Graziadei 2008, 444-445).

Art. 90 is clearly a combination of the aforementioned $\S \S 134$ and 138 of the German CC - and this fact causes some doubt as to whether the same provisions can work in the same way in two such distinct circumstances (Sugeno, 2002, p. 135) - and Art. 72 of the Chinese GMD CC was presumably in fact copied from the Japanese CC. Nonetheless, neither the Chinese GPCL, nor the Chinese CL preserved this provision.

\subsection{South Korea}

The South Korean Civil Code (Minbeob 민법, 民法), issued in 1958, was under great influence of the Japanese CC and Western civil law in general, especially the German CC (Zweigert and Kötz, 1998, pp. 298-299) and Swiss law (Kim, 2013, pp. 272-273). Since, like Japan, Korea also used its own traditional law before, the acceptance of European standards was quite unnatural for Korean society and thus it remains disputable whether its interpretation is similar to the European.

The code does not provide freedom of contract expressis verbis, but the rule is possible to be derived from human rights provided by Art. 10 of the South Korean Constitution (promulgated in 1987). This provision looks much like Art. 11 of the Japanese Constitution. Similarly in South Korea, freedom of contract is placed among fundamental human rights, so Art. 10 of the South Korean Constitution is perceived as a legal basis of this principle. ${ }^{1}$

According to the Korean $\mathrm{CC}$ parties are free to negotiate their contract by making an offer, and accepting it or constituting a counter-offer. It cannot be contrary to morality and social order - and social order in the article cited stands not only for the legal system, but also for other social rules, e.g. the Confucian tradition (Bucher, 2004, p. 103). Art. 103 of the Korean CC stipulates that a contract that violates gita sahoejilseoe 기타 사회질서에 'other social order' shall be void (Kim, 2000, pp. 9-10). 'Other social order' seems to have a broader meaning than the Chinese shehui jingji zhixu 社会经济秩序 'social economic order', and refers rather to social order rather than good morals. That entire condition included in this provision, which means that "good morals and other social order" is sometimes 
understood as a functional equivalent of American "public policy" (Korea Legislation Research Institute, 2012, p. 118).

\subsection{Vietnam}

The Vietnamese Civil Code, Luât Dân sụ, was - on the other hand heavily influenced by French law (Song, 1996, p. 633). Its new version was issued in 2005, and replaced previous one from 1995, abandoning, similarly to China, the concept of compulsory economic contracts (Westerman and McHugh, 1967, pp. 160-161). In the Vietnamese CC freedom of contract is expressed verbally in Art. 389. The only law-related prerequisite put in section 1 is pháp luât 'law' - which is present in China as falü 法律 'law'. Since the code is very concise, there are only few provisions on freedom of contract in general.

\section{Overview and conclusion}

In the presented legal systems the terms most commonly used in reference to freedom of contract include accordance with laws and publicity, whereas terms related directly to state were observed only in China. To make the analysis more clear, the most significant terms from the discussed systems are compiled in the table on the following pages. Due to the aim of the paper, the subject of the analysis is only general freedom of contract. That is why the issues of public law regulations and specific provisions of private law (e.g. consumer law) are omitted.

Table 1

\section{Terms used in context of limits of freedom of contract in the analysed countries}

\begin{tabular}{|c|c|c|c|c|}
\hline \multirow{2}{*}{ Country } & \multirow{2}{*}{$\begin{array}{l}\text { Source of the } \\
\text { regulation } \\
\text { and year }\end{array}$} & \multicolumn{3}{|c|}{ Limits: } \\
\hline & & Law & State & Publicity \\
\hline China & $\begin{array}{c}\text { Minfa Tongze } \\
\text { 民法通则 } \\
1986 \\
\text { Hetongfa } \\
\text { 合同法 } \\
1999\end{array}$ & $\begin{array}{c}\text { falü } \\
\text { 法律 } \\
\text { 'law' } \\
\text { falü, xingzheng } \\
\text { faguide } \\
\text { qiangzhixing } \\
\text { guiding } \\
\text { 法律、行政法规 } \\
\text { 的强制性规定 }\end{array}$ & $\begin{array}{c}\text { guojia zhilingxing } \\
\text { jihua } \\
\text { 国家指令性计划 } \\
\text { 'mandatory } \\
\text { state plan' } \\
\text { guojia zhengce } \\
\text { 国家政策 } \\
\text { 'state policy' }\end{array}$ & $\begin{array}{c}\text { shehui gonggong } \\
\text { liyi } \\
\text { 社会公共利益 } \\
\text { 'social public } \\
\text { interest' } \\
\text { shehui jingji zhixu } \\
\text { 社会经济秩序 } \\
\text { 'social economic } \\
\text { order' }\end{array}$ \\
\hline
\end{tabular}


Chinese Legal Terminology in European and Asian Contexts Analysed...

\begin{tabular}{|c|c|c|c|c|}
\hline \multirow{2}{*}{ Country } & \multirow{2}{*}{$\begin{array}{l}\text { Source of the } \\
\text { regulation } \\
\text { and year }\end{array}$} & \multicolumn{3}{|c|}{ Limits: } \\
\hline & & Law & State & Publicity \\
\hline & & $\begin{array}{l}\text { 'mandatory } \\
\text { provisions } \\
\text { of laws and } \\
\text { administrative } \\
\text { regulations' }\end{array}$ & $\begin{array}{c}\text { guijia liyi } \\
\text { 国家利益 } \\
\text { 'state interest' }\end{array}$ & $\begin{array}{c}\text { jiti liyi } \\
\text { 集体利益 } \\
\text { 'collective interest' }\end{array}$ \\
\hline France & $\begin{array}{l}\text { Code civil } \\
1804\end{array}$ & - & - & $\begin{array}{l}\text { l'ordre public } \\
\text { 'public order' }\end{array}$ \\
\hline Austria & $\begin{array}{c}\text { Allgemeines } \\
\text { bürgerliches } \\
\text { Gesetzbuch } \\
1811\end{array}$ & $\begin{array}{c}\text { ein gesetzliches } \\
\text { Verbot } \\
\text { [statutory } \\
\text { prohibition] }\end{array}$ & - & - \\
\hline Switzerland & $\begin{array}{l}\text { Obligationenrecht } \\
\text { /Droit des } \\
\text { obligations } \\
1883\end{array}$ & \begin{tabular}{|c|} 
illicite / \\
widerrechtlichen \\
[unlawful] \\
\\
droits attachés \\
à la personnalité / \\
das Recht der \\
Persönlichkeit \\
in sich schliesst \\
[rights of personal \\
privacy]
\end{tabular} & - & - \\
\hline Spain & $\begin{array}{c}\text { Código Civil } \\
1889\end{array}$ & $\begin{array}{l}\text { las leyes } \\
\text { [laws] }\end{array}$ & - & $\begin{array}{l}\text { el orden público } \\
\text { 'public order' }\end{array}$ \\
\hline Germany & $\begin{array}{l}\text { Bürgerliches } \\
\text { Gesetzbuch, } \\
1896\end{array}$ & $\begin{array}{c}\text { gesetzliches Verbot } \\
\text { [statutory } \\
\text { prohibition] } \\
\text { die } \\
\text { verfassungsmäßige } \\
\text { Ordnung } \\
\text { [constitutional } \\
\text { order] } \\
\text { gesetzlichen } \\
\text { Regelung } \\
\text { 'statutory } \\
\text { provisions' }\end{array}$ & - & - \\
\hline Italy & $\begin{array}{c}\text { Codice Civile } \\
1942\end{array}$ & \begin{tabular}{|c|} 
legge \\
'law' \\
norme imperative \\
'imperative rules' \\
norme corporative \\
'corporate rules'
\end{tabular} & - & $\begin{array}{l}\text { ordine pubblico } \\
\text { 'public order' }\end{array}$ \\
\hline
\end{tabular}




\begin{tabular}{|c|c|c|c|c|}
\hline \multirow{2}{*}{ Country } & \multirow{2}{*}{$\begin{array}{l}\text { Source of the } \\
\text { regulation } \\
\text { and year }\end{array}$} & \multicolumn{3}{|c|}{ Limits: } \\
\hline & & Law & State & Publicity \\
\hline Poland & $\begin{array}{l}\text { Kodeks cywilny } \\
1964 \text { (1990) }\end{array}$ & $\begin{array}{l}\text { ustawa } \\
\text { 'statute' }\end{array}$ & - & - \\
\hline Russia & $\begin{array}{c}\text { Grazhdanskiy } \\
\text { kodeks } \\
\text { Гражданский } \\
\text { кодекс } \\
1994\end{array}$ & 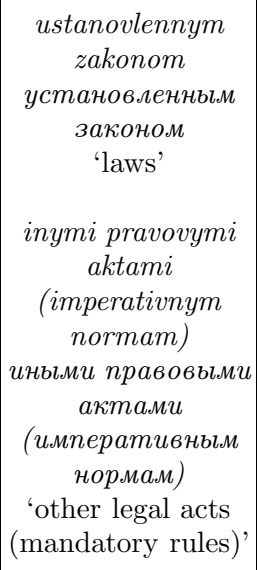 & - & - \\
\hline Czech Republic & $\begin{array}{c}\text { Občanský zákoník } \\
2014\end{array}$ & $\begin{array}{l}\text { právního řádu } \\
\text { 'legal system' } \\
\text { právo týkajici se } \\
\text { postavení osob } \\
\text { 'law related to the } \\
\text { status of persons' }\end{array}$ & - & $\begin{array}{l}\text { veřejný pořádek } \\
\text { 'public order' }\end{array}$ \\
\hline Japan & $\begin{array}{l}\text { Minpō } \\
\text { 民法 } \\
1896\end{array}$ & - & - & $\begin{array}{c}\text { kō no chitsujo } \\
\text { 公の秩序 } \\
\text { 'public order' } \\
\text { kōkyō no fukushi } \\
\text { 公共の福祉 } \\
\text { 'public welfare' }\end{array}$ \\
\hline South Korea & $\begin{array}{c}\text { Minbeob 민법 } \\
\text { (民法) } \\
1958\end{array}$ & - & - & $\begin{array}{l}\text { gita sahoejilseo } \\
\text { 기타 사회질서 } \\
\text { 'other social order' }\end{array}$ \\
\hline Vietnam & $\begin{array}{c}\text { Luâat Dân sụ } \\
2005\end{array}$ & $\begin{array}{l}\text { pháp luât } \\
\text { 'law' }\end{array}$ & - & - \\
\hline
\end{tabular}

Source of table: compiled by the author

The clause of lawfulness of contract was mentioned in 10 countries (including China), which is an expression of the fundamental rationality of the legal system, and terms related to publicity were observed in 7 among 13 analysed legal systems (again, including China). However, the terms re- 
ferring to the state were present only in Chinese law. Although law and public order in a few cases appear to be treated equivalently, it seems that public order is a term with a broader meaning, and may include law, while the opposite situation is impossible. These numbers were compiled in the graph below.

\section{Graph 1.}

Number of countries using terms referring to law, state and society as limits of freedom of contract

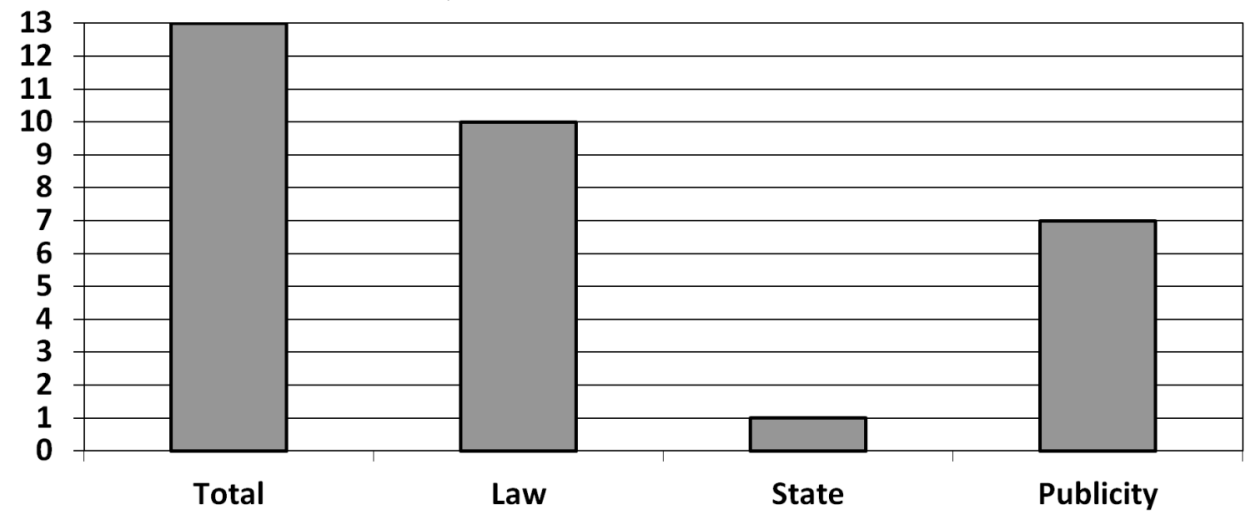

Source of graph: compiled by the author

Looking at the graph above it seems that two types of limitation, which were included in most of countries, are known in the Chinese legal system: limits related to law, and to the state. However, after thorough analysis in the above subsections, it appeared that some significant differences between these terms are observable. The first one is the number of provisions repeating the law-related restrictions. In China, these terms are put in numerous articles, sometimes just duplicating each other. In other countries there are often only single references to required lawfulness. Moreover, only China details in its provisions quite complicated term falü, xingzheng guiding 法律、行政法规 'laws and administrative regulations' - such an emphasis of administrative rules is not found in any of the examined foreign laws, which prefer shorter and general terms as 'law'. Secondly, Chinese law distinguishes many general terms that partially may absorb each other, such as shihei jingji zhixu 社会经济秩序 'social economic order', shehui gonggong liyi 社会公共利益 'social public interest', guojia liyi 国家利益 'state interest', shehui gonggong liyi 社会公共利益 'social public interest' and so on. In the analysed foreign laws the formula of 'public order' prevails, which, conversely, is absent in China in the context of contracts. These differences 


\section{Paulina Kozanecka}

are the most visible; there are certainly more of them, however such research would presumably require further academic study.

Nevertheless, this overview is just a brief analysis of how the Chinese legal terminology related to freedom of contract is expressed against the terms used in other selected legal systems. However, since the aim of this survey was only to examine Chinese terminology in a broader setting, the sample is still unrepresentative, and it would be inadvisable to draw some general conclusions on the basis of the previous examples.

\section{N O T E S}

1 The subject was consulted with Emilia Wojtasik, who currently is working on $\mathrm{PhD}$ dissertation on the subject of South Korean contract law in context of legal language and contract translation.

\section{R E F E R E N C E S}

Bucher, E. 2004. Law of Contract. In F. Dessemontet and T. Ansay (eds.), Introduction to Swiss Law, 3rd edition (pp. 103-137). The Hague - Boston London: Kluwer Law International.

Dajczak, W. 2012. The Nature of the Contract. Poznań: Wydawnictwo Naukowe UAM.

Foster, N. 2013. Austrian Legal System and Laws. Routledge.

$\mathrm{Fu}$, J. 2013. Freedom of Contract in the EU and China. Journal of International Commercial Law and Technology, 8, 274.

Gebhardt, I., and Schulz, T. 2003. Introduction to the German Civil Code. In I. Gebhardt, Y. Zhang, and R. Schröder (eds.), Comparative Analysis on the Chinese Contract Law (pp. 5-11). Berlin: Berliner Wissenschafts-Verlag $\mathrm{GmbH}$.

Han, S. 2012. A Snapshot of Chinese Contract Law from an Historical and Comparative Perspective. In Towards a Chinese Civil Code: Comparative and Historical Perspectives. Leiden/Boston: Martinus Nijhoff Publishers.

Hsu, S. C. 2007. Contract Law of the People's Republic of China. Minnesota Journal of International Law, 16, 115-162.

Kim, C. J. 2000. Korean Attitudes Toward Law. Pacific Rim Law \& Policy Journal, $10(1)$.

Kim, J. H. 2013. Development of Security Rights Law since the Codification of the Civil Code of Korea. Journal of Korean Law, 13, 271.

Kitagawa, Z. 2008. Development of Comparative Law in East Asia. In M. Reimann \& R. Zimmermann (eds.), The Oxford Handbook of Comparative Law (pp. 235-260). Oxford: Oxford University Press. 
Korea Legislation Research Institute. 2012. Introduction to Korean Law. Seoul: Springer Science and Business Media.

Kornet, N. 2010. Contracting in China: Comparative Obsrvations on Freedom of Contract, Contract Formation, Battle of Forms and Standard Form Contracts. Electronic Journal of Comparative Law, 14 (1), 1-31.

Kubacki, A. D. 2013. Teksty paralelne jako narzędzie pomocnicze przy sporządzaniu tłumaczeń (specjalistycznych). Comparative Legilinguistics, 13, 145-157.

Lando, O., Clive, E., Prum, A., and Zimmerman, R. (eds.). 2003. Principles of European Contract Law - Part III. The Hague - London - New York: Kluwer Law International.

Ling, B. 2002. Contract Law in China. Hong Kong: Sweet and Maxwell Asia.

Liu, G. 2017, "Social Public Interest" in Chinese Laws: A Fake or An Innovative Legal Term? Paper presented at the The 12th Conference on Translation, Interpreting and Comparative Legilinguistics. Kołobrzeg, Poland.

Matulewska, A. 2010. Deontic Modality and Modals in the Language of Contracts. Comparative Legilinguistics, 2, 75-92.

Matulewska, A. 2013. Legilinguistic Translatology: A Parametric Approach to Legal Translation. Bern: Peter Lang International Academic Publishers.

Morin, A. 2014. Efficiency and Swiss Contract Law. In K. Mathis (ed.), Law and Economics in Europe (pp. 207-230). Dordrecht: Springer Science and Business Media.

Radwański, Z. and Olejniczak, A. 2011. Prawo cywilne - część ogólna. Warszawa: C.H. Beck.

Song B. and Guo Y. 2013. Shiyong Minfa Zongze 实用民法总则. Beijing: Falü Chubanshe 法律出版社. Song S-H. (ed.). 1996. Korean Law in the Global Economy. Seoul: Bak Young Sa.

Soulier, J.-L. 2016. Ordinance of February 10, 2016 for the reform of French contract law: The principle of the binding force of contracts is considerably undermined by the new provisions of the French Civil Code.

Sójka-Zielińska, K. 2007. Kodeks Napoleona: Historia i współczesność. Warszawa: LexisNexis.

Sójka-Zielińska, K. 2009. Historia Prawa. Warszawa: LexisNexis.

Sugeno, K. 2002. Japanese Employment and Labor Law. Durham: Carolina Academic Press.

Sun, X., Ellinghaus, M. P. and Wright, E. W. (eds.). 2013. Zhongguo Renmin Gongheguo Hetong Fa fu Zuigao Renmin Fayuan guanyu Zhongguo Renmin Gongheguo Hetong Fa sifa jieshi (shuang yu) 中华人民共和国合同法附最高人 民法院关于适用《中华人民共和国合同法》司法解释 (双语版) Contract Law of the People's Republic of China with the Judicial Interpretations of the Supreme People's Court (Bilingual Version). Beijing: Qinghua Daxue Chubanshe 清华大学出版社. 
Wan, M. (ed.). 2012. Reading the Legal Case: Cross Currents Between Law and the Humanities. Oxon / New York: Routledge.

Wei, Z. 2013. Minfa 民法. Beijing: Beijing Daxue Chubanshe 北京大学出版社.

Wojciechowska, A. 2013. Granice swobody umów w hiszpańskim, angielskim i polskim języku prawnym (unpublished master thesis). Adam Mickiewicz University in Poznan, Poznań.

Wu, B., Zhang, L. and Luo, Y. 2012. Hetongfa Gailun 合同法概论. Chengdu: Bashu Shushe 巴蜀书社.

Zhang, M. 2006. Chinese Contract Law: Theory and Practice. Leiden/Boston: BRILL.

Zhou, X. 2003. Provisions on Validity of Contract in the Contract Law of China. In I. Gebhardt, Zhang Yuqing, and R. Schröder (eds.), Comparative Analysis on the Chinese Contract Law (pp. 93-105). Berlin: Berliner WissenschaftsVerlag GmbH.

Zweigert, K. and Kötz, H. 1998. An Introduction to Comparative Law. Oxford-New York: Clarendon Press and Oxford University Press. 